\title{
Hydraulics and hydrology on the Inland Ice
}

\author{
Henrik Højmark Thomsen and Ole B. Olesen
}

Glacier hydrological studies are carried out on the Greenland Inland Ice by the Geological Survey of Greenland (GGU) to assess the viability of possible hydro-electric power stations (Thomsen, 1986) in which surface meltwater from the Inland Ice margin is by far the most important source of water. Some of this water drains on the surface to the ice margin, but most of it disappears down into the ice through crevasses and moulins. Special emphasis is made on mapping the drainage of water in and under the ice to delineate drainage basins on the Inland Ice.

Studies of drainage within and beneath glaciers are numerous because of their applications in planning hydro-electric power stations and irrigation projects as well as in predicting catastrophic releases of water from ice-dammed lakes. Subglacial drainage mechanisms are also important for understanding glacier sliding and glacier surges. Reviews on the subject are given in Hooke (1989) and Röthlisberger \& Lang (1987). Most studies have been made on small, local glaciers but recently attention has been directed to the role of subglacial drainage in explaining ice streams (fast moving glaciers) draining major ice sheets (Engelhardt et al., 1990; Iken, 1990). Interest in the mechanics of ice streams is growing because of their significance in the response of ice sheets to climatic change.

GGU's investigations on the Inland Ice are therefore not only of practical importance for planning Greenland hydropower but also contribute to international research in glacier behaviour.

\section{Mapping and modelling meltwater drainage}

Meltwater drainage from the Inland Ice has been investigated on an ice sector of the Pâkitsoq basin north-east of Jakobshavn (Fig. 1) (Thomsen et al., 1988, $1989 \mathrm{~b}$ ). The work was carried out in connection with planning of hydro-electric power for the town of Jakobshavn/Ilulissat.

Surface drainage was mapped from aerial photographs and subglacial drainage was modelled from ice thickness data obtained by radio echo sounding. The model assumes that subglacial water pressure is a con- stant fraction of ice overburden pressure expressed in terms of a hydraulic factor. Calculated subglacial potentials were used for delineation of drainage basins. The derived drainage areas formed the basis for later modelling of runoff to be compared with the actual measured runoff (Braithwaite \& Thomsen, 1989).

The combined modelling of subglacial drainage and measured runoff indicates a high subglacial water pressure under this ice sheet sector. A water pressure of 70 percent of the ice overburden pressure gave the closest agreement between observed and calculated runoff.

\section{Field measurements}

To improve the knowledge of subglacial topography and drainage a programme of ice drilling and water pressure measurements was set up. This involved development of a hot-water drill with a capacity and design suitable for operations on the margin of the Greenland ice sheet (Olesen, 1989). The drill was successfully tested in the summer of 1987 (Olesen \& Clausen, 1988). Pressure sensor systems and dataloggers were developed for borehole logging.

Measurements of subglacial water pressure over the marginal zone of the Inland Ice at Pâkitsoq were made in 1988 (Thomsen et al., 1989a), 1989 (Thomsen \& Olesen, 1990) and in 1990 (Thomsen et al., 1991). In addition to data on subglacial water pressure, experience was gained in a variety of related aspects. These included countermeasures for preventing freezing of boreholes, blasting techniques in boreholes and artificial regulation of surface drainage.

\section{Some results and perspectives}

Water pressure measurements were obtained from 12 boreholes at three different locations on the ice sheet margin (Fig. 1). In all holes, borehole water-level dropped several metres below the ice surface when the drill stopped advancing at the bottom of the ice, or after blasting in the bottom of the hole. In some holes continuous water-level records were obtained and showed a marked diurnal oscillation (Fig. 2). In other holes only 


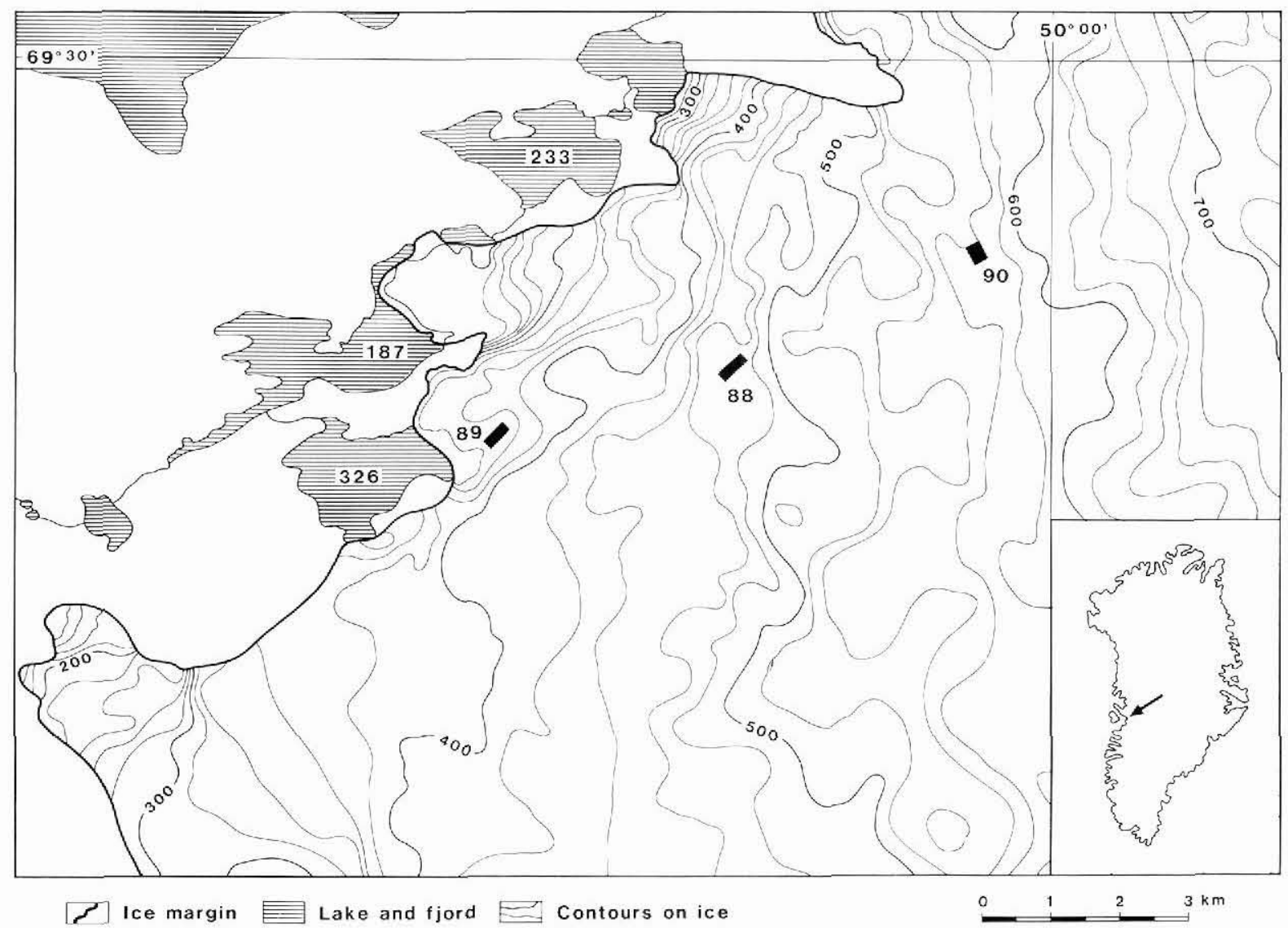

Fig. 1. Part of ice sheet sector at Pâkitsoq north-east of Jakobshavn, West Greenland. Lakes shown with horizontal lines. Contour interval on ice $20 \mathrm{~m}$; no contours shown on land areas. Locations on the ice are given where measurements of subglacial water pressure were obtained; numbers $(88,89,90)$ indicate year of measurements $(1988,1989,1990)$.

sporadic pressure measurements were obtained. From the nature of the pressure fluctuations there are good reasons to believe that the drill holes made connection with the subglacial drainage system.
The records show a generally high water pressure in accordance with the prediction of the modelling of subglacial drainage and runoff (Braithwaite \& Thomsen, 1989). Maximum and minimum recordings in the holes

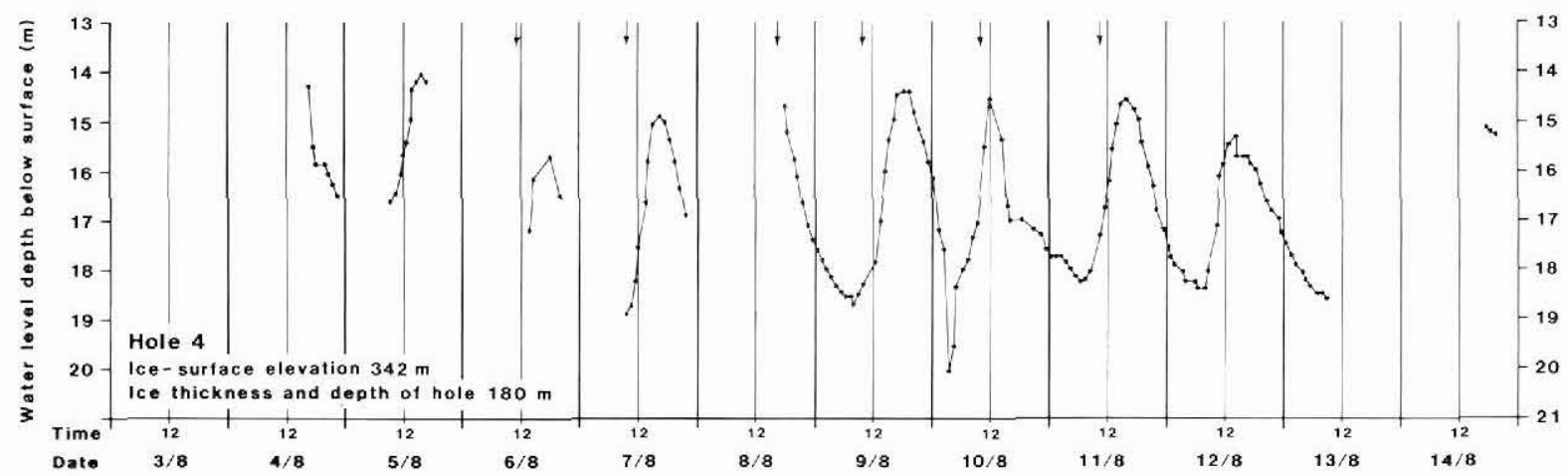

Fig. 2. Example of water-level recording in a borehole, obtained in 1988. Vertical arrows show times when water was pumped into the hole to prevent freezing. 
showed water pressure ranging from 105 to 79 percent of the ice overburden pressure. Furthermore, the data indicate that water pressure expressed as a percentage of ice overburden pressure decreases with increasing ice thickness.

Boreholes drilled to the bottom of fast moving ice streams, such as the ice stream B in the West Antarctic Ice Sheet (Engelhardt et al., 1990) and Jakobshavn Isbræ just south of the Pâkitsoq basin in West Greenland (Iken, 1990), also show high basal water pressures close to the flotation point. Compared to these ice streams, the Pâkitsoq area represents a relatively quiet sector of an ice sheet with a mean velocity in the range $50-150 \mathrm{~m}$ per year (Reeh, 1983; Thomsen, 1988). However, the basal water pressures are comparable to those found under ice streams. This shows that a high basal water pressure, as detected in boreholes, is not the only factor governing high velocities in ice streams.

Work is in progress to analyse further the water pressure data from Pâkitsoq. From combined recordings of water input to the basal system and the response of water-levels in boreholes it is hoped to define the type of subglacial drainage system beneath the ice sheet sector. This may lead to a refinement of the model for calculating the subglacial water potential.

\section{References}

Braithwaite, R. J. \& Thomsen, H. H. 1989: Simulation of run-off from the Greenland ice sheet for planning hydroelectric power, Jakobshavn/Ilulissat, West Greenland. Ann. Glaciol. 13, 12-15.

Engelhardt, H., Humphrey, N., Kamb, B. \& Fahnestock, M. 1990: Physical conditions at the base of a fast moving antarctic ice stream. Science 248, 57-59.

Hooke, R. LeB. 1989: Englacial and subglacial hydrology: a qualitative review. Arct. Alp. Res. 21, 221-233.

Iken, A. 1990: Tiefbohrungen im Jakobshavn Gletscher, Grönland. Bull. Eidgen. Techn. Hochsch. Zürich 228, 8-10.

Olesen, O. B. 1989: A Danish contribution to the family of hot-water glacier drills. In Rado, C. \& Beaudoing, D. (ed.) Ice core drilling. Proc. Third Internat. Workshop on Ice Drilling Technology, Grenoble, France, Oct. 1988, 140-148.
Olesen, O. B. \& Clausen, A. 1988: Test drilling with a hot water jet at the Inland Ice margin, Pâkitsup, central West Greenland. Rapp. Gronlands geol. Unders. 140, 121-124.

Reeh, N. 1983: Ikke-stationær beregningsmodel for Inlandsisens randzone. Grønlands geol. Unders. Gletscher-hydrol. Meddr 83/7, $81 \mathrm{pp}$.

Röthlisberger, H. \& Lang, H. 1987: Glacial hydrology. In Gurnell, A. M. \& Clark, M. J. (ed.) Glacio-fluvial sediment transfer; an alpine perspective, 207-284. London: John Wiley and Sons.

Thomsen, H. H. 1986: Is og vandkraft. Glaciologi i vandkraftprojektet bynære bassiner, 1982-1986. Glaciology and hydropower. Glaciology for local hydropower projects, 1982 1986. Grønlands geol. Unders. Gletscher-hydrol. Meddr 86/2, 73 pp.

Thomsen, H. H. 1988: Mass balance, ice velocity and ice temperature at the Inland Ice margin north-east of Jakobshavn, central West Greenland. Rapp. Grønlands geol. Unders. 140, 111-114.

Thomsen, H. H. \& Olesen, O. B. 1990 : Continued glaciological investigations with respect to hydropower and ice-climate relationships, at Pâkitsoq, Jakobshavn, West Greenland. Rapp. Grønlands geol. Unders. 148, 83-86.

Thomsen, H. H., Thorning, L. \& Braithwaite, R. J. 1988: Glacier-hydrological conditions on the Inland Ice north-east of Jakobshavn/Ilulissat, West Greenland. Rapp. Grønlands geol. Unders. 138, map with text.

Thomsen, H. H., Olesen, O. B., Braithwaite, R. J. \& Weidick, A. 1989a: Greenland ice-margin programme, a pilot study at Pâkitsoq, north-east of Jakobshavn, central West Greenland. Rapp. Grønlands geol. Unders. 145, 50-53.

Thomsen, H. H., Thorning, L. \& Olesen, O. B. 1989b: Applied glacier research for planning hydro-electric power, Ilulissat/Jakobshavn, West Greenland. Ann. Glaciol. 13, 257261.

Thomsen, H. H., Olesen, O. B., Braithwaite, R. J. \& Bøggild, C. E. 1991: Ice drilling and mass balance at Pâkitsoq, Jakobshavn, central West Greenland. Rapp. Grønlands geol. Unders. 152 (this volume).

H. H. T. \& O. B. O., Geological Survey of Greenland, Copenhagen. 